\title{
O SACI E O VALENTÃO
}

\author{
Lancast Mota
}

$\mathrm{Na}$ cidade apareceu

Um cabra valentão

Chutava gato

Chutava cão

Batia em homem

Batia em anão

\begin{abstract}
Chamaram o delegado
Delegado se escafedeu

Ligaram para o prefeito

Ninguém atendeu

$O$ padre veio

Mas o cabra era ateu
\end{abstract}

O valentão gostou do lugar

Disse: aqui vou morar

Escolheu um local

Uma mata de bambuzal

Com um facão

Pôs os bambus no chão

Dum gomo de bambu

Pulou um Saci

O valentão quando viu

Desatou a rir

Não sabia do mal

Feito a si

O Saci rodopiou

E cresceu

$\mathrm{O}$ valentão se assustou

E correu

O Saci o laçou

E uma surra lhe deu

O cabra mudou de nome

Não era mais valentão

Isso por causa das coisas

Que ele fez no calção

Lancast Mota é desenhista e roteirista, tendo criado diversos personagens para animação, cinema e televisão. Cearense, mora já há alguns anos em Porto Alegre. 
Quando ele aparecia

O povo dizia: Cagão! 